\title{
Introduction Part III European Soft Power and Christian Cultures at the Crossroads in Mandate Palestine
}

\author{
Heather J. Sharkey
}

\section{Setting the Stage}

This volume examines how European actors-ecclesiastical authorities, missionaries, scholars, diplomats and others - tried to assert cultural influence among Christian people or in Christian institutions in Palestine during the Mandate period, from 1918 to 1948. Two events bookended this period. The first event was the dissolution of the Ottoman Empire in the wake of World War I. The second was the debut of Israel and the concurrent displacement of the region's Muslims and Christians, whom we would now simply call Palestinians.

Recall the political contours of this era: From 1918 to 1948, Britain governed Palestine in a state of late colonial trusteeship. Palestine was one of the pieces of the vanquished Ottoman Empire, which the League of Nations ceded to Allied powers amid the post-war settlements. In Palestine as in Syria (under the French mandate) and Iraq (under another British mandate), the League of Nations granted stewardship over "peoples not yet able to stand by themselves under the strenuous conditions of the modern world". ${ }^{1}$ Yet, Palestine's situation was special. There Britain also adhered to the Balfour Declaration of 1917, by which it had lent support to establishing a Jewish

\footnotetext{
${ }^{1}$ League of Nations, "The Covenant of the League of Nations" (including amendments adopted to December, 1924) The Avalon Project: Yale Law School, http://avalon.law.yale. edu/20th_century/leagcov.asp. Accessed 31 May 2019.
}

H. J. Sharkey $(\bowtie)$

University of Pennsylvania, Philadelphia, PA, USA

e-mail: hsharkey@sas.upenn.edu 
homeland in the region. In this way, Britain endorsed the Zionist movement, a Jewish nationalist response to the accumulated European history of anti-Semitism. By the terms of the charter that confirmed its hold on Palestine, Britain made a vague and sweeping commitment to "ensuring that the rights and position of other sections of the population [would] not be prejudiced". ${ }^{2}$ By "other sections of the population", Britain signalled the ninety percent or so of the population that was not Jewish by 1918-the eighty-percent Muslim, and ten-percent Christian, part of the whole. ${ }^{3}$ Britain ultimately proved unable to reconcile promoting Jewish immigration and settlement with protecting the interests of the Muslims and Christians who were already there.

\section{The Christians of Palestine, and the European Deployment of Hard and Soft Power}

The political circumstances of the Mandate placed the Christians of Palestine in an awkward position. They found themselves stuck between Zionist Jews, who held aspirations for full-fledged statehood, and local Muslims, members of the religious group that had enjoyed political and legal dominance for centuries under successive Islamic dynasties (excluding periods of Crusader control during the twelfth and thirteenth centuries). The organisers of the conference from which this volume arose suggested that, amid mounting tensions, Britain became so caught up with trying to manage Jews and Muslims in Palestine that they largely neglected the Christians. Ignored by the Mandate authorities, the organisers hypothesised, local Christians responded by "over-proportionally invest[ing] in culture as a cornerstone of their identity" even as they observed unfolding events in Palestine with the same bewilderment and dismay that their Muslim neighbours were experiencing.

As the mandate-holder in Palestine, Britain claimed hard power: the theoretical monopoly over forms of violence that the sociologist Max Weber identified as the sine qua non of a state. ${ }^{4}$ But Britain was not the only European power vying for influence in Palestine. Other European actors continued ventures like mission schools and archaeological expeditions that they had begun in the late Ottoman era. These actors aimed to wield forms of what political analysts call "soft power"-non-military power-and to engage in what the organisers of this project have described as "cultural diplomacy". They formed international organisations and local societies; opened new Christian

\footnotetext{
${ }^{2}$ League of Nations, "The Palestine Mandate," The Avalon Project: Yale Law School, http:// avalon.law.yale.edu/20th_century/palmanda.asp. Accessed 31 May 2019.

${ }^{3}$ Edward Hagopian and A. B. Zahlan, "Palestine's Arab Population: The Demography of the Palestinians," Journal of Palestine Studies 3, no. 4 (1974): 34.

${ }^{4}$ Andreas Anter, "The Modern State and Its Monopoly on Violence," in The Oxford Handbook of Max Weber, Oxford Handbooks Online, eds. Edith Hanke, Lawrence Scaff, and Sam Whimser, February 2019, https://doi.org/10.1093/oxfordhb/9780190679545.013.13.
} 
and secular schools; published newspapers and scholarly journals; and more. Meanwhile, just as local Christian people found themselves in awkward positions under the mandate, so did churches and other institutions that foreign Christians led. Paolo Maggiolini considers in his chapter, for example, the career of Luigi Barlassina, Roman Catholic patriarch in Palestine from 1920 to 1947, who spent his tenure worrying about the future of Catholic institutions relative to the British, the Zionist Jews, the local Muslims, and assorted Christians... in short, relative to every political actor that had a stake in the region. Barlassina tried, inter alia, to cultivate international Roman Catholic support for interests in Palestine, by establishing a news centre in Belgium that sent dispatches to Catholics all over the world, as far afield as Korea. ${ }^{5}$

\section{European Christian Competition: Battling for Influence}

Together the articles in this section suggest another factor that helps to explain the marginalisation or relative invisibility of Arab Christians in this period-a factor wholly apart from the issue of British neglect. This was competition among Europeans for claims to Christian patrimony and influence- a competition so intense that it often obscured the needs and concerns of Palestinian Christians. British, French, and Russian powers competed with each other; the Vatican and the Orthodox patriarchates competed, too. Within the ranks of Christian groups that shared common theologies and doctrines, rivalries ruptured along national lines. French and Italian Catholic entities competed; Russians vied against Greeks (and vice versa) despite or because of their common Orthodoxy; Protestant Britons resentfully eyed the rise of American influence even as Anglo-American collaborations continued. On top of this were cross-sectarian permutations of Catholic-Protestant, Protestant-Orthodox and Orthodox-Catholic manoeuvres. Foreign Christian organisations, governments and interest groups were often so busy competing with each other that they seemed to forget that local Christians were there. An exception, as Inger Marie Okkenhaug suggests in her article here, was the Swedish school of the missionary Signe Ekblad, which involved local Arabs-and especially Arab women as schoolteachers-while cooperating closely with British Mandate authorities.

Complicating the story in the mandate era was the fact that foreign groups increasingly differed in their degree of Christian identification. Some were only what we might call "culturally" Christian (from historically Christian societies), while others were secular to the point of atheistic. Along these lines, Roberto Mazza considers in his article the outreach efforts of Mussolini's government-with its brew of Christian anticlerical, anti-Semitic

\footnotetext{
${ }^{5}$ Paolo Maggiolini noted the connections to Korea in his oral presentation at Leiden on March 27,2019 , and later, in an email to the author on October 3,2019, cited the likely source of the news as [Alessandro] Mombelli, the Swiss priest and journalist who was active in Palestine during the 1930s.
} 
and Islamophobic elements - and its use of radio programming. Idir Ouahes cites, in his study, the new French schools of the Mission Laïque, an avowedly secular organisation that promoted French, but not Christian, culture. The Russian case was even more dramatic, as Lora Gerd shows: the Soviet era initiated the near-complete retraction of Russian-led ecclesiastical activity in Palestine. Protestant organisations followed a different model: many of them proved adept at remaining sufficiently vague in their Christianness as to attract non-Christians as members or users of services. One example, again, was Signe Ekblad's Swedish school, which made no effort to convert Muslim students or even to woo other kinds of Christians to its sponsoring (Lutheran) church. Another example, cited in the article by Idir Ouahes, was Near East Relief, an American organisation that began from Protestant impulses but that evolved into a non-sectarian provider of humanitarian aid.

Idir Ouahes's epilogue is the only contribution to this book who discusses American actors. We may be tempted to exclude Americans from this chronicle of European engagement. And yet, most Americans in the Middle East were of not-so-distant European heritage, and used European cultural affinities - especially their use of the English language - to their advantage. And while many of the Americans had English, Scottish, and Irish forebears, others, like the famous Arabic Bible translator and author of Arabic scientific textbooks in Beirut, Cornelius Van Dyck, claimed Dutch Protestant roots-attesting to earlier routes of migration from the Netherlands to New Amsterdam (now New York) and its hinterlands. ${ }^{6}$

\section{Palestine at the Crossroads}

The essays in this section may ultimately tell us more about the history of Christians in Palestine than about the history of the Christians of Palestine. The long-term implications of the Russian, Swedish, Italian and other ventures covered here for the history and culture of Palestinian Christians remain uncertain and ambiguous.

Meanwhile, many European cultural agents used Palestine as a stage for their own performances of power and influence, and for their own constructions of national glory or ecclesiastical selfhood. Even a figure like Mussolini, for whom the Holy Land appears to have held little spiritual or devotional allure, inevitably gravitated to Palestine as a stage for Italian assertion, as Roberto Mazza shows in his study. Palestine's prestige as the cradle of Christianity was simply too strong to resist.

In sum, these studies offer potential for tracing transnational and supranational histories that illuminate the place and the idea of the Holy Land in global Christian cultures. They show, too, how Palestine featured as a forum

\footnotetext{
${ }^{6}$ The American missionary Samuel M. Zwemer, who lived for many years in Arabia and Egypt, had even stronger familial connections to the Netherlands: as the son of Dutch immigrants born in Michigan, he spoke Dutch, not English, as his first language.
} 
in what I have elsewhere called the "off-stage making" of national histories. Consider, again, the Russian example, as Lora Gerd has presented it. By examining the fate in Palestine of Russian Orthodox churches, scholarly institutes, pilgrimage-facilitating organisations, and more, we can see clearly from afar trajectories of Russian culture - and of Russian religious politics - before and after the Bolshevik Revolution of 1917.

Palestine has indeed been a crossroads, where for centuries European Christian people have met, ideas have circulated, and institutions have formed and reformed. Centred on the 1918-1948 period, the articles here point to the intersection of multiple European organisations and actors as they engaged with the region during a period of shaky British domination. This period witnessed dramatic upheaval in the land where Christianity was born and ended by leaving many of the local Christians of the land-the Palestinian Christians-uprooted and scattered.

\section{BIBLIOGRAPHY}

Anter, Andreas. "The Modern State and Its Monopoly on Violence." In The Oxford Handbook of Max Weber, Oxford Handbooks Online, edited by Edith Hanke, Lawrence Scaff, and Sam Whimser. February 2019. https://doi.org/10.1093/oxf ordhb/9780190679545.013.13.

Hagopian, Edward and A. B. Zahlan. "Palestine's Arab Population: The Demography of the Palestinians." Journal of Palestine Studies 3, no. 4 (1974): 32-73.

League of Nations. "The Covenant of the League of Nations" (including amendments adopted to December, 1924). The Avalon Project: Yale Law School. http://avalon.law.yale.edu/20th_century/leagcov.asp. Accessed 31 May 2019.

— . "The Palestine Mandate." The Avalon Project: Yale Law School. http://avalon.law.yale.edu/20th_century/palmanda.asp. Accessed 31 May 2019.

Sharkey, Heather J. "Innocents Abroad? American Missionaries and the Off-Stage Making of American Culture." For an invited panel on the United States as "A Nation of Emigrants," Organization of American Historians (OAH), Atlanta, April 10,2014 .

\footnotetext{
${ }^{7}$ Heather J. Sharkey, "Innocents Abroad? American Missionaries and the Off-Stage Making of American Culture," for an invited panel on the United States as "A Nation of Emigrants," Organization of American Historians (OAH), Atlanta, April 10, 2014.
} 
Open Access This chapter is licensed under the terms of the Creative Commons Attribution 4.0 International License (http://creativecommons.org/licenses/ by/4.0/), which permits use, sharing, adaptation, distribution and reproduction in any medium or format, as long as you give appropriate credit to the original author(s) and the source, provide a link to the Creative Commons license and indicate if changes were made.

The images or other third party material in this chapter are included in the chapter's Creative Commons license, unless indicated otherwise in a credit line to the material. If material is not included in the chapter's Creative Commons license and your intended use is not permitted by statutory regulation or exceeds the permitted use, you will need to obtain permission directly from the copyright holder. 